\title{
Textual references
}

Note: all links to on-line materials were tested and found to be working on 13 February 2019.

Acciaioli, Greg (2004) The consequences of conation: pedagogy and the inductive films of an ethical film-maker. In E. Douglas Lewis, ed., Timothy Asch and Ethnographic Film, pp. I23-48. London and New York: Routledge Harwood Anthropology.

Altman, Rick (2006) From lecturer's prop to industrial product: The early history of travel films. In Jeffrey Ruoff, ed., Virtual Voyages: Cinema and Travel, pp. 6I-76. Durham and London: Duke University Press.

Alvarez, Patricia (20I2) Interview with Véréna Paravel and J. P. Sniadecki. Fieldsights - Visual and New Media Review, Cultural Anthropology Online, I7 December 2012. www.culanth.org/fieldsights/33-interview-with-verena-paravel-and-j-p-sniadecki.

Amad, Paula (2010) Counter-Archive: Film, the Everyday, and Albert Kahn's Archives de la Planète. New York: Columbia University Press.

Anderson, Jane and María Montenegro (2017) Collaborative encounters in digital cultural property. In Jane L. Anderson and Haidy Geismar, eds, The Routledge Companion to Cultural Property. Abingdon and New York: Routledge.

Anonymous (1929) Kinematography. Notes and Queries. 5th edn, pp. 379-80. Edited for the British Association for the Advancement of Science by a Committee of Section H. London: Royal Anthropological Institute.

Asch, Timothy (I979) Making a film record of the Yanomamo Indians of Southern Venezuela. Perspectives on Film 2: 4-9, 44-9. University Park: Pennsylvania State University.

- (I986) How and why the films were made. In Linda Connor, Patsy Asch and Timothy Asch, Jero Tapakan: Balinese Healer. An Ethnographic Film Monograph, pp. 39-53. Cambridge: Cambridge University Press.

— (I988) Collaboration in ethnographic filmmaking: a personal view. In Jack R. Rollwagen, ed., Anthropological Filmmaking: Anthropological Perspectives on the Production of Film and Video for General Public Audiences, pp. I-29. Abingdon: Harwood Academic Publishers.

Asch, Timothy, John Marshall and Peter Spier (1973) Ethnographic film: structure and function. Annual Review of Anthropology 2: 179-85.

Asch, Timothy with Jesús Ignacio Cardozo, Hortensia Caballero and José Bortoli (I99I) The story we now want to hear is not ours to tell. Relinquishing control over representation: toward sharing visual communication skills with the Yanomami. Visual Anthropology 7(2): 102-6.

Aubert, Michelle and Jean-Claude Seguin (1996) La Production cinématographique des Frères Lumière. Éditions Mémoires de cinéma/Librarie du premier siècle du cinéma/CNC.

Aufderheide, Patricia (I995) The Video in the Villages project: video-making with and by Brazilian Indians. Visual Anthropology Review II (2): 83-93.

- (2008) 'You see the world of the Other and you look at your own': the evolution of the Video in the Villages project. Journal of Film and Video 6o(2): 26-34. 
Baily, John (20I7) War, Exile and the Music of Afghanistan: The Ethnographer's Tale. SOAS Ethnomusicology Series. London and New York: Ashgate-Routledge.

Balard, Martine (1999) Dahomey 1930: mission catholique et culte vodoun. L'aeuvre de Francis Aupiais (1877-1945), missionaire et ethnographe. Paris: L'Harmattan.

- (2007) Les combats du père Aupiais (I877-1945), missionaire et ethnographe du Dahomey pour la reconnaissance africaine. Histoire et missions chrétiennes 2(2): 74-93.

Balikci, Asen (1988) Anthropologists and ethnographic filmmaking. In Jack Rollwagen, ed., Anthropological Filmmaking: Anthropological Perspectives on the Production of Film and Video for General Public Audiences, pp. 3I-45. Abingdon: Harwood Academic Publishers.

- (1989) Anthropology, film and the Arctic peoples. Anthropology Today 5(2): 3-Io.

- (I995) Reconstructing cultures on film. In Paul Hockings, ed., Principles of Visual Anthropology, 2nd edn, pp. I8I-9I. Berlin and New York: Mouton de Gruyter.

Banks, Marcus (1988) The non-transparency of ethnographic film. Anthropology Today $4(5): 2-3$.

- (I992) Which films are the ethnographic films? In Peter Crawford and David Turton, eds, Film as Ethnography, pp. II6-30. Manchester and New York: Manchester University Press.

- (1994) Television and anthropology: an unhappy marriage? Visual Anthropology 7(I): $2 \mathrm{I}-45$.

Banks, Marcus and David Zeitlyn (2015) Visual Methods in Social Research, 2nd edn. London: Sage Publishing.

Barbash, Ilisa (2007) Out of words: a conversation with Robert Gardner. In Ilisa Barbash and Lucien Taylor, eds, The Cinema of Robert Gardner, pp. 93-II8. Oxford: Berg.

Barley, Nigel (1989) Native Land.Viking Penguin.

Barnouw, Erik (1983) Documentary: A History of the Non-fiction Film. Revised edn. Oxford: Oxford University Press.

Bateson, Gregory and Margaret Mead (1942) Balinese Character: A Photographic Analysis. New York: New York Academy of Sciences.

Batty, Philip (2013) 'Primitive Blacks face White man's laws': the 1932 anthropological expedition to Mt. Liebig, Central Australia. In Joshua A. Bell, Alison K. Brown, and Robert J. Gordon, eds, Recreating First Contact: Expeditions, Anthropology, and Popular Culture, pp. 197-2I4. Washington DC: Smithsonian Institution Scholarly Press.

Baxter, P. T. W. (1977) The Rendille. RAIN 20: 7-9.

Bazin, André (2005) What is Cinema? Essays selected and translated by Hugh Gray, vol. I. Berkeley, Los Angeles, London: University of California Press.

Beausoleil, Jeanne, ed. (I996) Pour une reconnaissance africaine, Dahomey 1930; Des images au service d'une idée. Boulogne: Musée Albert-Kahn.

Beidelman, Thomas O. (I992) Millenium. Cultural Anthropology 7(4): 508-I5.

Bell, Joshua A., Alison K. Brown and Robert J. Gordon (2013) Appendix - Films, Technology, and Institutional Histories. In Joshua A. Bell, Alison K. Brown, and Robert J. Gordon, eds, Recreating First Contact: Expeditions, Anthropology, and Popular Culture, pp. 24I-52. Washington DC: Smithsonian Institution Scholarly Press.

Benthall, Jonathan (2014) Fail better? Reflections on Face Values and Millenium. Anthropology Today 30(2): 25 .

Berner, Margit (2006) From 'prisoners of war' to proof of paternity: racial anthropologists and the meaning of 'Others' in Austria. In Marius Turda and Paul Weindling, eds, 'Blood and Homeland': Eugenics and Racial Nationalism in Central and Southeast Europe 1900-1940, pp. 4I-53. Budapest: Central European University Press.

Berthe, Jamie (2018) Au-delà des critique entomologiques: Rouch et le cinéma africain, un autre point de vue. In Rina Sherman, ed., Dans le sillage de Jean Rouch:Témoinages et essais, pp. I27-42. Paris: Éditions de la Maison des sciences de l'homme.

Biella, Peter, Napoleon A. Chagnon and Gary Seaman, eds (1997) Yanomamö Interactive: The Ax Fight. CD-ROM. Case Studies in Cultural Anthropology Multimedia Series. Harcourt Brace College Publishers. 
Bishop, John (2007) Life by myth: the development of ethnographic filming in the work of John Marshall. In Beate Engelbrecht, ed., Memories of the Origins of Visual Anthropology, pp. 87-94. Frankfurt: Peter Lang.

Bloom, Peter J. (2006) Trans-Saharan Automotive Cinema. Citroën-, Renault-, and Peugeot-sponsored Documentary Interwar Crossing Films. In Jeffrey Ruoff, ed., Virtual Voyages: Cinema and Travel, pp. 139-56. Durham and London: Duke University Press.

- (2008) French Colonial Documentaries: Mythologies of Humanitarianism. Minneapolis: University of Minnesota Press.

Blue, James (1996) Jean Rouch: interviewed by James Blue. In Kevin Macdonald and Mark Cousins, eds, Imagining Reality: The Faber Book of Documentary, pp. 268-70. London and Boston: Faber \& Faber. Originally published in Film Comment 2(2), Spring 1964.

Bradburd, Daniel (2013) Grass before Kong - 'Natives' in the films of Merian Cooper and Ernest Schoedsack. In Joshua A. Bell, Alison K. Brown and Robert J. Gordon, eds, Recreating First Contact: Expeditions, Anthropology, and Popular Culture, pp. 55-7I. Washington DC: Smithsonian Institution Scholarly Press.

Bringa, Tone (I995) Being Muslim the Bosnian Way: Identity and Community in a Central Bosnian Village. Princeton: Princeton University Press.

Brody, Hugh (1975) The People's Land: Eskimos and Whites in the Eastern Arctic. Harmondsworth: Penguin.

- (I977) Seeming to be real: Disappearing World and the film in Pond Inlet. Cambridge Anthropology. Special Issue Ethnographic Film, pp. 22-3I.

Brown, Liz (1978) The two worlds of Marrakech. Screen I9(2): 85-II8.

Browne, Colin (2014) Unmasking the Documentary: Notes on the Anxiety of Edward Curtis. In Brad Evans and Aaron Glass, eds, Return to the Land of the Head Hunters: Edward S. Curtis, the Kwakwaka'wka, and the Making of Modern Cinema, pp. I67-89. Seattle: University of Washington Press and the Bill Holm Center, Burke Museum.

Bruzzi, Stella (2000) New Documentary: A Critical Introduction. London and New York: Routledge.

Bryson, Ian (2002) Bringing to Light: A History of Ethnographic Filmmaking at the Australian Institute of Aboriginal and Torres Strait Islander Studies. Canberra: Aboriginal Studies Press.

- (2007) Visual anthropology: the AIATSIS contribution. In Beate Englebrecht, ed., Memories of the Origins of Ethnographic Film, pp. 295-305. Frankfurt am Main: Peter Lang.

Bugos, Paul, Jr, Stephan Carter and Timothy Asch (1975) The Ax Fight: Film Notes. Cambridge, Mass.: Documentary Educational Resources.

Caiuby, Novaes, Sylvia, Eduardo da Cunha and Paul Henley (2017) The first documentary? Luiz Thomaz Reis, the Rondon Commission and the making of Rituais e Festas Borôro (I9I7) Visual Anthropology 30(I): IO5-46.

Caplan, Patricia (1993) Review of We Are All Neighbours. Anthropology Today 9(6): 20-2.

- (2005) In search of the exotic: a discussion of the BBC2 series Tribe. Anthropology Today 2I (2): 3-7.

- (2013) An anthropologist among the filmmakers. A cautionary tale: Part I. The politics of production. Anthropology Today 29(6): 23-6.

- (20I4) An anthropologist among the filmmakers. A cautionary tale: Part 2. The politics of circulation. Anthropology Today 30(I): I5-I9.

Castaing-Taylor, Lucien (20I6) Sweetgrass: 'Baaaaah. Bleeeeeet'. From an introductory text and interview with Jay Kuehner at Vancouver International Film Festival, 2009. In Rupert Cox, Andrew Irving and Christopher Wright, eds, Beyond Text?: Critical Practices and Sensory Anthropology, pp. I48-55. Manchester: Manchester University Press.

Castro, Teresa (2008) Les Archives de la Planète et les rythmes de l'Histoire. 1895. Mille huit cent quatre-vingt-quize 54: 56-8I.

Chagnon, Napoleon (I997) Yanomamö, sth edn. Harcourt Brace College Publishers. 
Chalfen, Richard (I992) Picturing culture through indigenous imagery: a telling story. In Peter Crawford and David Turton, eds, Film as Ethnography, pp. 222-4I. Manchester: Manchester University Press.

- (2007) The Worth/Adair Navajo experiment - Unanticipated results and reactions. In Beate Englebrecht, ed., Memories of the Origins of Ethnographic Film, pp. I65-75. Frankfurt am Main: Peter Lang.

Chopra, Radikha (1989) Robert Gardner's Forest of Bliss: a review. Society of Visual Anthropology Newsletter 5(I): 2-3.

Clifford, James (1988a) Power and dialogue in ethnography: Marcel Griaule's initiation. In James Clifford, The Predicament of Culture: Twentieth Century Ethnography, Literature and Art, pp. 55-9I. Cambridge, Mass.: Harvard University Press.

- (I988b) On ethnographic surrealism. In James Clifford, The Predicament of Culture: Twentieth Century Ethnography, Literature and Art, pp. II7-5I. Cambridge, Mass.: Harvard University Press.

- (I99I) Documents: a decomposition. Visual Anthropology Review 7I: 62-83.

Clifford, James and George Marcus, eds (1986) Writing Culture: The Poetics and Politics of Ethnography. Berkeley: University of California Press.

Colleyn, Jean-Paul (2005) Jean Rouch: an anthropologist ahead of his time. American Anthropologist IO7(I): II2-I5.

Connor, Linda H., Patsy Asch and Timothy Asch (1986) Jero Tapakan: Balinese Healer. An ethnographic film monograph. Cambridge: Cambridge University Press.

Connor, Linda H. and Patsy Asch (2004) Subjects, images, voices: representation of gender in the films of Tim Asch. In E. Douglas Lewis, ed., Timothy Asch and Ethnographic Film, pp. I63-84. London and New York: Routledge Harwood Anthropology.

Crawford, Peter (1992) Grass: the visual narrativity of pastoral nomadism. In Peter Crawford and Jan Ketil Simonsen, eds, Ethnographic Film Aesthetics and Narrative Traditions, pp. I2 I-38. Aarhus: Intervention Press.

- (2004) Respect the moment! A retrospective of the cinematographic work of Gary Kildea. In Pille Runnel, ed., Tartu visuaalse kultuuri päevad, pp. 75-9I. Estonian National Museum. Also at www.slideshare.net/Antropologiavisualuff/ respect-the-moment-gary-kildea-27229077.

Curtis, Edward S. (19I5) In the Land of the Head Hunters. Indian Life and Lore Series. World Book Company (reprinted in 1992).

de Brigard, Emilie (I995) The history of ethnographic film. In Paul Hockings, ed., Principles of Visual Anthropology, 2nd edn, pp. I3-43. Berlin and New York: Mouton de Gruyter.

de Bromhead, Antoinette (2014) A Film-maker's Odyssey: Adventures in Film and Anthropology. Højbjerg: Intervention Press.

de Heusch, Luc (2007) The prehistory of ethnographic film. In Beate Engelbrecht, ed., Memories of the Origins of Visual Anthropology, pp. I5-22. Frankfurt: Peter Lang.

de Pastre, Béatrice with Philippe Costantini (2017) Jean Rouch, l'Homme-Cinéma: Découvrir les films de Jean Rouch. Paris: CNC/Bnf/Somogy.

De Rosa, Francesca (2018) Arquivos colonais e representações da alteridade nos documentários do Estado Novo. In Jorge Seabra, ed., Cinemas en português. Moçambique: Auto e Heteroperceções, pp. IOI-I6. Imprensa da Universidade de Coimbra.

Deger, Jennifer (2006) Shimmering Screens: Making Media in an Aboriginal Community. Minneapolis: University of Minneapolis Press.

Deveson, Philippa with Ian Dunlop (2012) The ethnographic filmmaking of Ian Dunlop in a decade of change. In Natasha Fijn, ed., Perspectives on Ethnographic Film. Special edition of Humanities Research, vol. XVIII, no. I, pp. 47-78.

Douglas, Mary (1975) If the Dogon ... In Mary Douglas, Implicit Meanings: Essays in Anthropology, I24-4I. London and Boston: Routledge \& Kegan Paul.

- (1995) Réflexions sur le renard pâle et deux anthropologies: à propos du surréalisme et de l'anthropologie française. In Christopher W. Thompson, ed., L'Autre et le Sacré: surréalisme, cinéma, ethnologie, pp. I99-2I8. Paris: L'Harmattan. 
Dunlop, Ian (1979) Ethnographic film-making in Australia: the first seventy years (I898-I968). Aboriginal History 3(I-2): III-I9 (reprinted in 1983 in Studies in Visual Communication 9(I): II-I8).

- (2003) Background notes for Peoples of the Australian Western Desert and Desert People. shop.nfsa.gov.au/people-of-the-australian-western-desert.

Durington, Matthew and Jay Ruby (20II) Ethnographic film. In Marcus Banks and Jay Ruby, eds, Made to Be Seen: Perspectives on the History of Visual Anthropology, pp. I90-208. Chicago and London: University of Chicago Press.

Durosay, Daniel (1993) Introduction. In Marc Allégret, Carnets du Congo: voyage avec André Gide, 2nd edn, pp. II-57. Paris: CNRS.

Eaton, Michael, ed. (1979) Anthropology, Reality, Cinema: The Films of Jean Rouch. London: British Film Institute.

Elder, Sarah (1995) Collaborative filmmaking: an open space for making meaning, a moral ground for ethnographic film. Visual Anthropology Review II (2): 94-IOI.

Evans, Brad (1998) Catherine Russell's recovery of the Head-Hunters. Visual Anthropology II $(3): 22$ I -42 .

- (20I4) Indian movies and the vernacular of modernism. In Brad Evans and Aaron Glass, eds, Return to the Land of the Head Hunters: Edward S. Curtis, the Kwakwaka'wka, and the Making of Modern Cinema, pp. I90-2 II. Seattle: University of Washington Press and the Bill Holm Center, Burke Museum.

Evans, Brad and Aaron Glass, eds (2014) Return to the Land of the Head Hunters: Edward S. Curtis, the Kwakwaka'wka, and the Making of Modern Cinema. Seattle: University of Washington Press and the Bill Holm Center, Burke Museum.

Faris, James (1992) Anthropological transparency: film, representation and politics. In Peter Crawford and David Turton, eds, Film as Ethnography, pp. I7I-82. Manchester: Manchester University Press.

Fausto, Carlos (20II) No registro da cultura: o cheiro do branco e o cinema dos índios. In Ana de Carvalho, Ernesto de Carvalho and Vincent Carelli, eds, Video nas Aldeias - 25 anos, pp. I60-8. Livraria Cultura. See also www.videonasaldeias.org.br/2009/ biblioteca.php? $=30$.

Feld, Steven (2016) Film Review - Kalanda:The Knowledge of the Bush. Visual Anthropology Review 32(I): 84-5.

Fernea, Elizabeth Warnock (1998) In Search of Islamic Feminism: One Woman's Global Journey. New York: Anchor Books.

Ferrarini, Lorenzo (2017) Enactive Filmmaking: Rethinking Ethnographic Cinema in the First Person. Visual Anthropology Review 33(2): I30-40.

Feuchtwang, Stephan (1983) The Kazakhs of China. RAIN 57: Io.

Fieschi, Jean-André and André Téchiné (1967) Jean Rouch: 'Jaguar'. Cahiers du Cinéma I95: I7-20.

Flaherty, Robert (1996) Robert Flaherty Talking. In Kevin Macdonald and Mark Cousins, eds, Imagining Reality: The Faber Book of Documentary, pp. 36-43. London and Boston: Faber \& Faber. Originally published in I950.

Flaherty, Robert in collaboration with Frances Hubbard Flaherty (1924) My Eskimo Friends: 'Nanook of the North'. London: Heinemann.

Flores, Carlos (2007) Sharing anthropology: collaborative video experiences among Maya film-makers in post-war Guatemala. In Sarah Pink, ed., Visual Interventions: Applied Visual Anthropology, pp. 209-24. New York and Oxford: Berghahn.

Forman, Denis (1985) International Festival of Ethnographic Film: Opening speech, 24 September. Anthropology Today I(6): 2-4.

Fox, James (1977) Harvest of the Palm: Ecological Change in Eastern Indonesia. Cambridge, Mass.: Harvard University Press.

- (2004) Efforts and events in a long collaboration: working with Tim Asch on ethnographic films on Roti in eastern Indonesia. In E. Douglas Lewis, ed., Timothy Asch and Ethnographic Film, pp. 83-96. London and New York: Routledge Harwood Anthropology. 
Fuhrmann, Wolfgang (2007) First contact: the beginning of ethnographic filmmaking in Germany, 1900-I930. History of Anthropology Newsletter 34(I): 3-9.

- (2013) Ethnographic film practices in silent German cinema. In Joshua A. Bell, Alison K. Brown, and Robert J. Gordon, eds, Recreating First Contact: Expeditions, Anthropology, and Popular Culture, pp. 4I-54. Washington DC: Smithsonian Institution Scholarly Press.

- (2015) Imperial Projections: Screening the German Colonies. Oxford and New York: Berghahn Press.

Fulchignoni, Enrico (2003) Jean Rouch with Enrico Fulchignoni: ciné-anthropology. In Steven Feld, ed., Ciné-Ethnography, pp. I47-87. Minneapolis and London: University of Minnesota Press. Originally published in French in 198I.

Gabriel, Teshome H. (1982) Third Cinema in the Third World: The Aesthetics of Liberation. Ann Arbor, Mich.: UMI Research Press.

Gardner, Robert (1972) On the making of Dead Birds. In Karl Heider and Robert Gardner, The Dani of West Irian: An Ethnographic Companion to the Film Dead Birds. New York: MSS Modular Publications Inc.

- (2006) The Impulse to Preserve: Reflections of a Filmmaker. New York: Other Press LLC.

- (2010) Kalahari journal. In Charles Warren, ed., Just Representations: Robert Gardner, pp. 2-30. Cambridge, Mass.: Studio7Arts and Peabody Museum Press.

Gardner, Robert and Ákos Östör (200I) Making Forest of Bliss: Intention, Circumstance and Chance in Non-fiction Film. Cambridge, Mass. and London: Harvard Film Archive.

Gauthier, Lionel and Laurent Pellé (2000) Jean Rouch: Récits photographiques. Paris: Éditions Muséum national d'Histoire naturelle - Musée de l'Homme.

Geertz, Clifford (1988) Works and Lives: The Anthropologist as Author. Stanford: Stanford University Press.

Gellner, David N. (2015) How not to make a documentary: A personal view of the movie 'Manakamana'.www.academia.edu/IoIIO376/How_Not_to_Make_a_Documentary_ A_Personal_View_of_the_Movie_Manakamana.

Georgakas, Dan, Udayan Gupta and Judy Janda (2003) The politics of visual anthropology. In Steven Feld, ed., Ciné-Ethnography, pp. 210-25. Minneapolis and London: University of Minnesota Press.

Gidley, Mick (1982) From the Hopi Snake Dance to the 'The Ten Commandments': Edward S. Curtis as filmmaker. Studies in Visual Communication 8(3): 70-9.

- (20I4) Edward Curtis and In the Land of the Head Hunters. Four Contexts. In Brad Evans and Aaron Glass, eds, Return to the Land of the Head Hunters: Edward S. Curtis, the Kwakwaka'wka, and the Making of Modern Cinema, pp. 42-60. Seattle: University of Washington Press and the Bill Holm Center, Burke Museum.

Ginsburg, Faye (I99I) Indigenous media: Faustian contract or global village? Cultural Anthropology 6(I): 92-II2.

— (1994) Culture/media. A(mild) polemic. Anthropology Today Io(2): 5-I5.

- (I995a) Mediating culture: indigenous media, ethnographic film, and the production of identity. In Leslie Devereaux and Roger Hillman, eds, Fields of Vision: Essays in Film Studies, Visual Anthropology, and Photography, pp. 256-91. Berkeley, Los Angeles and London: University of California Press.

- (I995b) The parallax effect: the impact of aboriginal media on ethnographic film. Visual Anthropology Review II (2): 64-76.

- (1997) Comment on 'Televisualist Anthropology' by James F.Weiner. Current Anthropology 38(2): 213-I6.

- (20II) Native intelligence: a short history of debates on indigenous media and ethnographic film. In Marcus Banks and Jay Ruby, eds, Made to be Seen: Perspectives on the History of Visual Anthropology, pp. 234-55. Chicago and London: University of Chicago Press.

- (20r8) Decolonizing documentary on-screen and off: sensory ethnography and the aesthetics of accountability. Film Quarterly 72(I): 39-49. 
Gitlin, Daniella (2012) To experience Song of Ceylon. Senses of Cinema 62. sensesofcinema.com/2012/feature-articles/to-experience-song-of-ceylon/.

Glass, Aaron (20I4) The Kwakwaka'wka Business of Showing:Tradition Meets Modernity on the Silver Screen and the World Stage. In Brad Evans and Aaron Glass, eds, Return to the Land of the Head Hunters: Edward S. Curtis, the Kwakwaka'wka, and the Making of Modern Cinema, pp. 3I5-57. Seattle: University of Washington Press and the Bill Holm Center, Burke Museum.

Glass, Aaron and Brad Evans (2OI4) Introduction. Edward Curtis meets the Kwakwaka'wka: Cultural Encounter and Indigenous Agency In the Land of the Head Hunters. In Brad Evans and Aaron Glass, eds, Return to the Land of the Head Hunters: Edward S. Curtis, the Kwakwaka'wka, and the Making of Modern Cinema, pp. 3-39. Seattle: University of Washington Press and the Bill Holm Center, Burke Museum.

Gluckman, Max (1958) Analysis of a social situation in modern Zululand. Rhodes-Livingstone Papers no. 28. Originally published in I940.

Gonzalez, Nancie L. (I993) An argument about a film. In Jay Ruby, ed., The Cinema of John Marshall, pp. I79-93. Abingdon: Harwood Academic Publishers.

Gordon, Robert J. (2003) Introduction: A Kalahari Family. Visual Anthropology Review I9 (I-2): IO2-I3.

Gordon, Robert J. and Stuart S. Douglas (2000) The Bushman Myth: The Making of a Namibian Underclass. Boulder: Westview Press.

Gordon, Robert J., Alison K. Brown and Joshua A. Bell (20I3) Expeditions, their films and histories: an introduction. In Joshua A. Bell, Alison K. Brown and Robert J. Gordon, eds, Recreating First Contact: Expeditions, Anthropology, and Popular Culture, pp. I-30. Washington DC: Smithsonian Institution Scholarly Press.

Gregor, Thomas A. and Daniel R. Gross (2004) Guilt by association: the culture of accusation and the American Anthropological Association's investigation of Darkness in El Dorado. American Anthropologist io6(4): 687-98.

Griaule, Marcel (1957) Méthode de l'ethnographie. Paris: Presses Universitaires de France.

Griffiths, Alison (2002) Wondrous Difference: Cinema, Anthropology and Turn-of-the-Century Culture. New York: Columbia University Press.

Grimshaw, Anna (I995) Conversations with Anthropological Film-makers: Melissa LlewelynDavies. Prickly Pear Press, no. 8. Also available at www.thememorybank.co.uk/ pricklypear/8.pdf.

- (200I) The Ethnographer's Eye: Ways of Seeing in Anthropology. Cambridge: Cambridge University Press.

Grimshaw, Anna and Paul Hockings (20II) Two recent films from David MacDougall. Visual Anthropology 24(4): 39I-9.

Grimshaw, Anna and Nikos Papastergiadis (I995) Conversations with Anthropological Film-makers: David MacDougall. Prickly Pear Press, no. 9. Also available at www.thememorybank.co.uk/pricklypear/9.pdf.

Grimshaw, Anna and Amanda Ravetz (2009) Observational Cinema: Anthropology, Film, and the Exploration of Social Life. Bloomington: Indiana University Press.

Guldin, Jere (20I4) In The Land of the Head Hunters: Reconstruction, not restoration. In Brad Evans and Aaron Glass, eds, Return to the Land of the Head Hunters: Edward S. Curtis, the Kwakwaka'wka, and the Making of Modern Cinema, pp. 260-8. Seattle: University of Washington Press and the Bill Holm Center, Burke Museum.

Guynn, William (I998) The art of national projection. Basil Wright's Song of Ceylon. In Barry Keith Grant and Jeannette Sloniowski, eds, Documenting the Documentary, pp. 83-98. Detroit: Wayne State University Press.

Haddon, Alfred (I90I) Head-hunters: Black, White and Brown. London: Methuen.

Haffner, Pierre (I996) Les avis de cinq cinéastes d'Afrique noire. In René Prédal, ed., Jean Rouch ou le ciné-plaisir. Special edition of CinémAction, vol. 8I, pp. 89-IO3. Éditions Corlet. First published in I982.

Harper, Douglas, ed. (I994) Cape Breton I952: The photographic vision of Timothy Asch. Visual Sociology 9 (2). 
- (2004) An ethnographic gaze: scenes in the anthropological life of Timothy Asch. In E. Douglas Lewis, ed., Timothy Asch and Ethnographic Film, pp. 17-56. London and New York: Routledge Harwood Anthropology.

Heidegger, Martin (1978) Letter on humanism. In David F. Krell, ed., Martin Heidegger: Basic Writings, pp. 213-65. London: Routledge. Originally published in 1947.

Heider, Karl (I976) Ethnographic Film. Austin: University of Texas Press.

- (2007) Gardner's first shots: vectored landscapes. In Ilisa Barbash and Lucien Taylor, eds, The Cinema of Robert Gardner, pp. 79-92. Oxford: Berg.

Hempel, Paul (2009) Theodor Koch-Grünberg and visual anthropology in early twentiethcentury German anthropology. In Christopher Morton and Elizabeth Edwards, eds, Photography, Anthropology and History: Expanding the Frame, pp. 193-2 I9. Ashgate.

Henley, Paul (2009) The Adventure of the Real: Jean Rouch and the Craft of Ethnographic Cinema. Chicago and London: University of Chicago Press.

- (2013a) From documentation to representation: recovering the films of Margaret Mead and Gregory Bateson. Visual Anthropology 26(2): 75-108.

- $(2013 b)$ Thick inscription and the unwitting witness: reading the films of Alfred Haddon and Baldwin Spencer. Visual Anthropology 26(5): 383-429.

- (20I7) Avant Jean Rouch: le cinéma 'ethnographique' français tourné en Afrique subsaharienne. Journal des africanistes $87(\mathrm{I} / 2): 34-62$.

- (2018) The authoring of Observational Cinema: conversations with Colin Young. Visual Anthropology 3I(3): 193-235.

- (2020) L'Aventure du réel: Jean Rouch et la pratique du cinéma ethnographique. Trans. Joëlle Hauzeur. Presses universitaires de Rennes.

Hercus, Luise (I980) How we danced the Mudlunga. Aboriginal History 4(I): 4-3I.

Hinkson, Melinda (2008) New media projects atYuendumu: towards a history and analysis of intercultural engagement. In Luke Taylor et al., eds, The Power of Knowledge, the Resonance of Tradition, pp. I57-68. Canberra: Australian Institute of Aboriginal and Torres Strait Islander Studies.

Hockings, Paul (1988) Gone with the Gael: Filming an Irish village. In Jack Rollwagen, ed., Anthropological Filmmaking:Anthropological Perspectives on the Production of Film and Video for General Public Audiences, pp. I43-59. Abingdon: Harwood Academic Publishers.

Holm, Bill (20I4) Foreword. In Brad Evans and Aaron Glass, eds, Return to the Land of the Head Hunters: Edward S. Curtis, the Kwakwaka'wka, and the Making of Modern Cinema, pp.xii-xvii. Seattle: University of Washington Press and the Bill Holm Center, Burke Museum.

Holm, Bill and George Irving Quimby (1980) Edward S. Curtis in the Land of the War Canoes: A Pioneer Cinematographer in the Pacific Northwest. Thomas Burke Memorial Washing State Museum Monograph no. 2. Seattle and London: University of Washington Press.

Homiak, John P. (I990a) Melville J. Herskovits: motor behavior and the imaging of Afro-American Culture. Visual Anthropology 3(I): II-29.

(I990b) The anthropological visualization of Haiti: reflections on the films of Melville Herskovits and Maya Deren. Commission on Visual Anthropology Review, Spring I990: I3-2I.

- (2003) A Kalahari Family: some thoughts on reflexivity, voice and social location. Visual Anthropology Review I9(I-2): I28-34.

— (2013) Foreword. In Joshua A. Bell, Alison K. Brown and Robert J. Gordon, eds, Recreating First Contact: Expeditions, Anthropology, and Popular Culture, pp. v-xii. Washington DC: Smithsonian Institution Scholarly Press.

Homiak, John P. and Keyan G. Tomaselli (1999) Structured absences: shot logs on the Marshall family expeditionary films, I950-I958. Visual Anthropology I2(2-3): 289-338.

Hughes-Freeland, Felicia (2006) Tribes and tribulations: a response to Pat Caplan. Anthropology Today 22(2): 22-3.

Ichioka, Yasuko (I995) Ethnographic filmmaking for Japanese television. In Paul Hockings, ed., Principles of Visual Anthropology, 2nd edn, pp. 44I-56. Berlin and New York: Mouton de Gruyter. 
Jacknis, Ira (1987) The picturesque and the scientific: Franz Boas' plan for anthropological filmmaking. Visual Anthropology I(I): 59-64.

Jamin, Jean (I99I) Anxious science: ethnography as a devil's dictionary. Visual Anthropology Review 7(I): 84-9I.

Jenkins, Alan (I986) Disappearing World goes to China: a production study of anthropological films. Anthropology Today 2(3): 6-I3.

Jensen, Gordon D. and Luh Ketut Suryani (1992) The Balinese People: A Reinvestigation of Character. Singapore and Oxford: Oxford University Press.

Jolly, Éric (2014) Démasquer la société dogon. Sahara-Soudan, janvier-avril 1935. Les Carnets de Bérose, no. 4. Série Missions, enquêtes et terrains - Années I930. Lahic/Ministère de la Culture et de la Communication. www.berose.fr/IMG/pdf/carnet_be_rose_4.pdf.

- (2017) Cinéma ethnographique. In À la naissance de l'ethnologie française. Les missions ethnographiques en Afrique subsaharienne (1928-1939). naissanceethnologie.fr/exhibits/ show/cinema.

Jordan, Pierre-L. (1992) Cinéma: Premier Contact - Premier Regard. Marseille: Musées de Marseille/Images en Manoeuvres Editions.

Kildea, Gary (2007) Interview of Gary Kildea. www.dspace.cam.ac.uk/handle/1810/183663.

Kildea, Gary and Margaret Willson (1986) Interpreting ethnographic film: an exchange about Celso and Cora. Anthropology Today 2(4): I5-I7.

King, Eleanor M. (1993) Fieldwork in Brazil: Petrullo's visit to the Yawalpiti. Expedition 35(3): 34-43. Available at www.penn.museum/documents/publications/expedition/ PDFs/35-3/Fieldwork.pdf.

Knight, John (1993) Making a tribal difference in the modern world. Anthropology Today 9(I): 22-4.

Kuklick, Henrika (2013) Afterword. In Joshua A. Bell, Alison K. Brown and Robert J. Gordon, eds, Recreating First Contact: Expeditions, Anthropology, and Popular Culture, pp. 23I-9. Washington DC: Smithsonian Institution Scholarly Press.

Laracy, Hugh (2013) Patrick O'Reilly (1900-I988): Bibliographer of the Pacific. In Hugh Laracy, Watriama and Co.: Further Pacific Portraits, pp. 257-65. Canberra: ANU Press.

Lawson, Mark (1993) An original of the species. Independent (IO February 1993). www.independent.co.uk/arts-entertainment/television-I472093.html.

Leprohon, Pierre (1945) L'Exotisme et le Cinéma: les 'chasseurs d'images' a la conquête du monde ... Paris: Éditions Susse.

Lewis, E. Douglas (1988) People of the Source. The Social and Ceremonial Order of Tana Wai Brama on Flores. Verhandelingen van het Instituut voor Taal-, Land- en Volkenkunde no. I35. Dordrecht, Holland and Providence, Rhode Island: Foris Publications.

- (2004a) Introduction. Timothy Asch in America and Australia. In E. Douglas Lewis, ed., Timothy Asch and Ethnographic Film, pp. I-I6. London and New York: Routledge Harwood Anthropology.

- (2004b) From event to ethnography: film-making and ethnographic research in Tana 'Ai, Flores, eastern Indonesia. In E. Douglas Lewis, ed., Timothy Asch and Ethnographic Film, pp. 97-I22. London and New York: Routledge Harwood Anthropology.

- (2004c) Person, event, and the location of the cinematic subject in Timothy Asch's films on Indonesia. In E. Douglas Lewis, ed., Timothy Asch and Ethnographic Film, pp. 263-82. London and New York: Routledge Harwood Anthropology.

Lindstrom, Lamont (2013) On safari with Martin and Osa Johnson. In Joshua A. Bell, Alison K. Brown and Robert J. Gordon, eds, Recreating First Contact: Expeditions, Anthropology, and Popular Culture, pp. I47-6I. Washington DC: Smithsonian Institution Scholarly Press.

Llewelyn-Davies, Melissa (1978) Two contexts of solidarity among pastoral Maasai women. In Patricia Caplan and Janet Burja, eds, Women United, Women Divided, pp. 206-37. London and Bloomington: Tavistock.

- (I98I) Women, warriors, and patriarchs. In Sherry B. Ortner and Harriet Whitehead, eds, Sexual Meanings: The Cultural Construction of Gender and Sexuality, pp. 330-58. Cambridge and New York: Cambridge University Press. 
Loizos, Peter (1980) Granada Television's Disappearing World series: an appraisal. American Anthropologist 82(3): 573-94.

— (1993) Innovation in Ethnographic Film: From Innocence to Self-consciousness 1955-1985. Manchester: Manchester University Press.

- (I995) Robert Gardner's Rivers of Sand: toward a reappraisal. In Leslie Devereaux and Roger Hillman, eds, Fields of Vision: Essays in Film studies, Visual Anthropology, and Photography, pp. 3II-25. Berkeley, Los Angeles, London: University of California Press.

Lutkehaus, Nancy C. (2004) Man, a course of study: situating Tim Asch's pedagogy and ethnographic films. In E. Douglas Lewis, ed., Timothy Asch and Ethnographic Film, pp. 57-73. London and New York: Routledge Harwood Anthropology.

Lydall, Jean (1992) Filming The Women Who Smile. In Peter Ian Crawford and Jan Ketil Simonsen, eds, Ethnographic Film Aesthetics and Narrative Traditions, pp. I4I-58. Aarhus: Intervention Press.

- (2008) Intimacy, Integrity, and Indulgence in Anthropological Film. Journal of Film and Video 6o(2): 35-49.

Lydall, Jean and Ivo Strecker (1978) A critique of Lionel Bender's review of Rivers of Sand. American Anthropologist 80(4): 945-6.

MacDonald, Scott (2013) American Ethnographic Film and Personal Documentary: The Cambridge Turn. Berkeley, Los Angeles, London: University of California Press.

- (2015) Avant-Doc: Intersections of Documentary and Avant-Garde Cinema. Oxford University Press.

MacDougall, David (I992a) Complicities of style. In Peter Ian Crawford and David Turton, eds, Film as Ethnography, pp. 90-8. Manchester: Manchester University Press. Also published in Transcultural Cinema, pp. 140-9, Princeton: Princeton University Press, 1998.

- (I992b) Photo Wallahs: an encounter with photography. Visual Anthropology 8(2): 96-Ioo. (I995a) Beyond observational cinema. In Paul Hockings, ed., Principles of Visual Anthropology, 2nd edn, pp. II5-32. Berlin and New York: Mouton de Gruyter.

- (I995b) The subjective voice in ethnographic film. In Leslie Devereaux and Roger Hillman, eds, Fields of Vision: Essays in Film Studies, Visual Anthropology, and Photography, pp. 217-55. Berkeley, Los Angeles, London: University of California Press.

- (1997) The visual in anthropology. In Marcus Banks and Howard Morphy, eds, Rethinking Visual Anthropology, pp. 276-95. New Haven and London:Yale University Press.

- (I998a) Transcultural Cinema. Edited and with an introduction by Lucien Taylor. Princeton: Princeton University Press.

- (I998b) Visual anthropology and the ways of knowing. In David MacDougall, Transcultural Cinema, pp. 6I-92. Princeton: Princeton University Press. Originally published in 1995 .

- (I998c) Whose story is it? In David MacDougall, Transcultural Cinema, pp. I50-64. Princeton: Princeton University Press. Originally published in I99I.

— (I998d) Subtitling ethnographic films. In David MacDougall, Transcultural Cinema, pp. I65-76. Princeton: Princeton University Press. Originally published in I995.

(I998e) Unprivileged camera style. In David MacDougall, Transcultural Cinema, pp. 199-208. Princeton: Princeton University Press. Originally published in 1982.

- (I998f) When less is less. In David MacDougall, Transcultural Cinema, pp. 209-23. Princeton: Princeton University Press. Originally published in 1992.

- (200I) Renewing ethnographic film. Is digital video changing the genre? Anthropology Today I7(3): I5-2I.

- (2006a) Introduction: meaning and being. In The Corporeal Image: Film, Ethnography, and the Senses, pp. I-9. Princeton: Princeton University Press.

- (2006b) Films of childhood. In The Corporeal Image: Film, Ethnography, and the Senses, pp. 67-93. Princeton: Princeton University Press.

- (2006c) Social aesthetics and the Doon School. In The Corporeal Image: Film, Ethnography, and the Senses, pp. 94-II9. Princeton: Princeton University Press. 
- (2006d) Doon School reconsidered. In The Corporeal Image: Film, Ethnography, and the Senses, pp. I20-44. Princeton: Princeton University Press.

- (2007) Colin Young, ethnographic film and the film culture of the I96os. In Beate Englebrecht, ed., Memories of the Origins of Ethnographic Film, pp. I23-3I. Frankfurt am Main: Peter Lang.

- (2019) The Looking Machine: Essays on Cinema, Anthropology and Documentary Filmmaking. Manchester: Manchester University Press.

MacFarlane, Alan (2007) Interview of David MacDougall. Available at www.youtube.com/ watch?v=4oyjVMfebsM.

- (20I0) Early Ethnographic Film in Britain: A Reflection on the Work of Christoph von Fürer Heimendorf. Visual Anthropology 23(5): 375-97.

Malinowski, Bronislaw (1932a) Argonauts of the Western Pacific: An Account of Native Enterprise and Adventure in the Archipelagos of Melanesian New Guinea. 2nd impression. London: Routledge \& Kegan Paul. First published in 1922.

- (1932b) The Sexual Life of Savages in North-Western Melanesia:An Ethnographic Account of Courtship, Marriage, and Family Life Among the Natives of the Trobriand Islands, British New Guinea, 3rd edn. London: Routledge \& Kegan Paul. First published in 1929.

Mamber, Stephen (1974) Cinema Verité in America: Studies in Uncontrolled Documentary. Cambridge, Mass. and London: MIT Press.

Marcus, Alan (2006) Nanook of the North as primal drama. Visual Anthropology 19(3-4): $2 \mathrm{OI}-22$.

Marcus, George E. and Dick Cushman (1982) Ethnographies as texts. Annual Review of Anthropology II: 25-69.

Marshall, John (1993) Filming and learning. In Jay Ruby, ed., The Cinema of John Marshall, pp. I-I33. Abingdon: Harwood Academic Publishers.

Marshall Thomas, Elizabeth (1959) The Harmless People. Harmondsworth: Penguin.

Martinez, Wilton (1995) The challenges of a pioneer: Tim Asch, Otherness, and film reception. Visual Anthropology Review II (I): 53-82.

Martins, Luciana (2007) Illusions of power: vision, technology and the geographical exploration of the Amazon, 1924-1925. Journal of Latin American Cultural Studies I6(3): $285-307$.

- (2012) Geographical exploration and the elusive mapping of Amazonia. The Geographical Review IO2(2): 225-44.

Mattei Muller, Marie-Claude (2007) Lengua y Cultura Yanomami. Diccionario ilustrado Yanomami-Español/ Español-Yanomami. Caracas: UNESCO.

McCarty, Mark (1995) McCarty's Law and How to Break It. In Paul Hockings, ed., Principles of Visual Anthropology, 2nd edn, pp. 69-75. Berlin and New York: Mouton de Gruyter.

McLuhan, Marshall and Quentin Fiore (1967) The Medium is the Massage: An Inventory of Effects. New York: Random House.

Mead, Margaret (1995) Visual anthropology in a discipline of words. In Paul Hockings, ed., Principles of Visual Anthropology, 2nd edn, pp. 3-Io. Berlin and New York: Mouton de Gruyter.

Mead, Margaret and Gregory Bateson (1977) Margaret Mead and Gregory Bateson on the use of the camera in anthropology. Studies in the Anthropology of Visual Communication 4(2): $78-80$.

Michaels, Eric (1986) Aboriginal Invention of Television: Central Australia 1982-1986. Canberra: Australian Institute of Aboriginal Studies.

Miller, Cynthia (2007) Ethnographic documentary filmmakers Sarah Elder and Leonard Kamerling: an interview. Post Script 27 (I). www.questia.com/read/IGI-I7637I864/ ethnographic-documentary-filmmakers-sarah-elder-and.

Mir-Hosseini, Ziba (2002) Negotiating the politics of gender in Iran: an ethnography of a documentary. In Richard Tapper, ed., The New Iranian Cinema, pp. I67-99. London: I. B. Tauris.

Morin, Edgar (2003) Chronicle of a film. In Steven Feld, ed. and trans., Ciné-Ethnography. Minneapolis and London: University of Minnesota Press, pp. 229-65. Originally published in French in 1962. 
Morphy, Howard (1984) Journey to the Crocodile's Nest: An Accompanying Monograph to the Film Madarrpa Funeral at Gurka'wuy. Afterword by Ian Dunlop. Canberra:Australian Institute of Aboriginal Studies.

- (I994) The interpretation of ritual: reflections from film on anthropological practice. Man (NS) 29(I): II7-46.

- (2007) The aesthetics of communication and the communication of cultural aesthetics: a perspective on Ian Dunlop's films of Aboriginal Australia. In Beate Englebrecht, ed., Memories of the Origins of Ethnographic Film, pp. 321-40. Frankfurt am Main: Peter Lang.

- (20I2) Becoming a visual anthropologist. In Natasha Fijn, ed., Perspectives on Ethnographic Film. Special edition of Humanities Research, vol. XVIII, no. I, pp. I5-46.

Morris, Alan G. (1987) The reflections of the collector: San and Khoi skeletons in museum collections. The South African Archaeology Bulletin 42(I): I2-22.

Morris, Rosalind C. (I994) New Worlds from Fragments: Film, Ethnography, and the Representation of Northwest Coast Cultures. Boulder and Oxford: Westview Press.

Mortimer, Lorraine (2019) Roger Sandall's Films and Contemporary Anthropology: Explorations in the Aesthetic, the Existential, and the Possible. Bloomington: Indiana University Press.

Moser, Brian (1988) Foreword. In André Singer with Leslie Woodhead, Disappearing World: Television and Anthropology, pp. 9-I4. London: Boxtree in association with Granada Television.

Moser, Brian and Donald Tayler (1963) Tribes of the Piraparaná. The Geographical Journal I29(4): 437-49.

Muenala,Yauri (2018) Kikinkunawan: visualidades comunes. La autorepresentación en la práctica audiovisual de realizadores otovalos kichwa. Quito: Abya-Yala.

Murray Levine, Alison (2005) Film and colonial memory: La Croisière noire 1924-2004. In Alec G. Hargreaves, ed., Memory, Empire, and Postcolonialism: Legacies of French Colonialism, pp. 8I-97. Lexington Books, Rowman \& Littlefield.

- (2010) Framing the Nation: Documentary Film in Interwar France. New York and London: Continuum.

Myers, Fred R. (1988) From ethnography to metaphor: recent films from David and Judith MacDougall. Cultural Anthropology 3(2): 205-20.

- (1993) Djungguwan at Gurka'wuy by Ian Dunlop. Film Review. American Anthropologist 95(I): $250-2$.

Naficy, Hamid (2006) Ethnographic and expedition films about nomadic tribes - the case of Grass (1925). In Jeffrey Ruoff, ed., Virtual Voyages: Cinema and Travel, pp. II7-38. Durham and London: Duke University Press.

Nichols, Bill (2004) What really happened: a reassessment of The Ax Fight. In E. Douglas Lewis, ed., Timothy Asch and Ethnographic Film, pp. 229-37. London and New York: Routledge Harwood Anthropology.

O’Reilly, Patrick (1970) Le 'documentaire' ethnographique en Océanie. In Jean Rouch and Monique Salzmann, eds, Premier catalogue sélectif international de films ethnographiques sur la région du Pacifique, pp. 28I-305. Paris: UNESCO.

Oppitz, Michael (I988) A day in the city of death. 'Forest of Bliss' (by Robert Gardner) - a film review. Anthropos 83: 210-I2.

Östör, Ákos (1994) Forest of Bliss: Film and Anthropology. East-West Film Journal 8(2): 70-IO4.

Oswalt, Wendell H. (2008) This Land Was Theirs: A Study of Native North Americans, 9th edn. Oxford: Oxford University Press.

Parry, Jonathan (1988) Comment on Robert Gardner's 'Forest of Bliss'. Society for Visual Anthropology Newsletter 4(2): 4-7.

Peleg, Hila (2017) We are somatic creatures: Hila Peleg in conversation with Rosalind Nashashibi,Véréna Paravel and Lucien Castaing-Taylor, and Ben Russell. South Magazine no. 9/documenta I4, no. 4. www.documenta I4.de/en/south/252I6_we_are_somatic_ creatures_hila_peleg_in_conversation_with_rosalind_nashashibi_ve_re_na_paravel_ and_lucien_castaing_taylor_and_ben_russell. 
Pequet, Luc, ed. (2017) Jean Rouch: ethnologue et cinéaste. Special edition of the Journal des africanistes, vol. 87(I-2). Paris: Société des africanistes.

Peterson, Leighton C. (2013) Reclaiming Diné film: visual sovereignty and the return of Navajo Film Themselves. Visual Anthropology Review 29(I): 29-4I.

Petriç,Vlada (1987) Constructivism in Film: The Man with the Movie Camera, A Cinematic Analysis. Cambridge: Cambridge University Press.

Piault, Colette (2007a) Forbidden speech/controlled speech: some observations on the role of the word in Rouch's films. Visual Anthropology Review 23(I): 38-42. Originally published in French in 1996.

- (2007b) Speech-dominated or dominating?: an interview with Jean Rouch. Visual Anthropology Review 23(I): 43-53. Originally published in French in 1996.

Piault, Marc-Henri (2000) Anthropologie et cinéma: passage à l'image, passage par l'image. Paris: Éditions Nathan.

Pink, Sarah (20II) Digital visual anthropology: potentials and challenges. In Marcus Banks and Jay Ruby, eds, Made to be Seen: Perspectives on the History of Visual Anthropology, pp. 209-33. Chicago and London: University of Chicago Press.

Potts, Rowena (2015) A conversation with David MacDougall: Reflections on the childhood and modernity workshop films. Visual Anthropology Review 3I(2): 190-200.

Prins, Harald E. L. and John Bishop (200I-2) Edmund Carpenter: explorations in media anthropology. Visual Anthropology Review I7(2): IIO-40.

Quinn, Frederick (I980) Beti society in the nineteenth century. Africa 5O(3): 293-304.

Rassool, Ciraj (20I5) Re-storing the skeletons of empire: return, reburial and rehumanisation in Southern Africa. Journal of Southern African Studies 4I(3): 653-70.

Richardson, Michael (I990) Report on RAI questionnaire. Anthropology Today 6(I): II-I2.

Robbins, Steven L. (2008) From Revolution to Rights in South Africa: Social Movements, NGOs and Popular Politics after Apartheid. James Curry and University of KwaZulu-Natal Press.

Rondon, Cândido Mariano da Silva, ed. (1946) Índios do Brasil-do Centro, Noroeste e Sul do Mato Grosso. vol. I. Conselho Nacional de Proteção aos Índios, Ministério de Agricultura. Rio de Janeiro. Available online via the Museo do Índio, Rio de Janeiro, at www.docvirt.com/docreader.net/DocReader.aspx?bib=museudoindio\&pagfis=.

Rony, Fatimah Tobing (1996) The Third Eye: Race, Cinema and Ethnographic Spectacle. Durham and London: Duke University Press.

Rotha, Paul with Basil Wright (1980) Nanook and the North. Studies in Visual Communication 6(2): 33-60.

Rouch, Jean (I955) Á propos de films ethnographiques. Positif I4-I5: I45-9.

— (I956) Migrations au Ghana (Gold Coast): Enquête 1953-I955. Journal de la Société des Africanistes 26: 33-196.

- ed. (1967a) Premier catalogue sélectif international de films ethnographiques sur l'Afrique noire. Paris: UNESCO. Available at unesdoc.unesco.org/ark:/48223/pfoooooo 3622.

- (1967b) Situation et tendances du cinéma en Afrique. In Jean Rouch, ed., Premier catalogue sélectif international de films ethnographiques sur l'Afrique noire, pp. 374-408. Paris: UNESCO.

— (1968) Le film ethnographique. In Jean Poirier, ed., Encyclopédie de la Pléiade: ethnologie générale, pp. 429-7I. Paris: Gallimard.

- (1989) La religion et la magie songhay, 2nd edn. Bruxelles: Éditions de la Université de Bruxelles.

- (I995a) The camera and man. In Paul Hockings, ed., Principles of Visual Anthropology, 2nd edn, pp. 79-98. Berlin and New York: Mouton de Gruyter.

- (1995b) Our totemic ancestors and crazed masters. In Paul Hockings, ed., Principles of Visual Anthropology, 2nd edn, pp. 217-32. Berlin and New York: Mouton de Gruyter.

- (I995c) L'autre et le sacré: jeu sacré, jeu politique. In Christopher W. Thompson, ed., L'Autre et le Sacré: surréalisme, cinéma, ethnologie, pp. 407-3I. Paris: L’Harmattan.

- (2003a) On the vicissitudes of the self: the possessed dancer, the magician, the sorcerer, the filmmaker, and the ethnographer. In Steven Feld, ed., Ciné-Ethnography, 
pp. 87-IOI. Minneapolis and London: University of Minnesota Press. Originally published in French in I97I.

- (2003b) The mad fox and the pale master. In Steven Feld, ed., Ciné-Ethnography, pp. IO2-26. Minneapolis and London: University of Minnesota Press. Translated from a text originally published in 1978 .

- (2009) Essai sur les avatars de la personne du possédée, du magicien, du corcier, du cinéaste et de l'ethnographe. In Jean-Paul Colleyn, ed., Jean Rouch: cinéma et anthropologie, pp. I4I-53. Cahiers du Cinéma/essais. Paris: INA (Institut national de l'audiovisuel). Originally published in 1975 .

Rouch, Jean and Monique Salzmann, eds (1970) Premier catalogue sélectif international de films ethnographiques sur la région du Pacifique. UNESCO: Paris. Available at unesdoc.unesco.org/images/0000/00003I/003II7fb.pdf.

Rowbottom, Anne (2002a) Subject positions and 'real royalists': monarchy and vernacular civil religion. In Nigel Rapport, ed., British Subjects: An Anthropology of Britain, pp. 3I-48. Oxford: Berg.

- (2000b) Following the Queen: the place of the Royal Family in the context of Royal visits and civil religion. Sociological Research Online 7(2). www.socresonline.org.uk/7/2/ rowbottom.html.

Ruby, Jay (1975) Is an ethnographic film a filmic ethnography? Studies in the Anthropology of Visual Communication 2(2): I04-II. Also available at astro.temple.edu/\%7Eruby/ ruby/is.html.

- (I980) Franz Boas and early camera study of behavior. Kinesics Report 3(I): 6-II, I6. Also available at astro.temple.edu/ ruby/ruby/boas.html.

_ (I995a) Out of synch: the cinema of Tim Asch. Visual Anthropology Review II(I): I9-35.

- (I995b) The moral burden of authorship in ethnographic. Visual Anthropology Review II (2): $77-82$.

- (2000) Picturing Culture: Explorations of Film and Anthropology. Chicago and London: University of Chicago Press.

Ruoff, Jeff (2002) Around the world in eighty minutes: the travel lecture film. Visual Anthropology I5(I): 9I-II4.

Russell, Catherine (1999) Experimental Ethnography: The Work of Film in the Age of Video. Durham and London: Duke University Press.

Sandall, Roger (I972) Observation and identity. Sight and Sound 4I(4): I92-6.

- (I975) Ethnographic film documentaries. In Paul Hockings, ed., Principles of Visual Anthropology, Ist edn, pp. I25-32. Berlin and New York: Mouton de Gruyter.

Sariskova, Oksana (2017) Screening Soviet Nationalities. Kulturfilms from the Far North to Central Asia. London and New York: I. B. Tauris.

Saunders, Dave (2007) Direct Cinema: Observational Documentary and the Politics of the Sixties. London and New York: Wallflower Press.

Schiwy, Freya (2009) Indianizing Film: Decolonization, the Andes and the Question of Technology. Rutgers University Press.

Schrire, Carmel (2003) The conciliators: Bushmania and the nightmare of survival. Visual Anthropology Review 19(2-3): 160-5.

Schüller, Dietrich (1987) Buschmann spricht in den Phonographen - Film von Rudolf Pöch, 1908. Wissenschaftlichen Film(Wien) nos 36/37: 133-9.

Serceau, Daniel (I996) Entretien avec Pierre Braunberger. In René Prédal, ed., Jean Rouch ou le ciné-plaisir. Special issue of CinémAction, vol. 8I, pp. I70-I. Condé-sur-Noireau: Éditions Corlet-Télérama. Originally published in 1982 in René Prédal, ed., Jean Rouch, un griot gaulois. Special issue of CinémAction, vol. I7, pp. I58-60. Paris: L'Harmattan.

Seton, Marie (I97I) Basil Wright's Song of Ceylon. In Lewis Jacobs, ed., The Documentary Tradition, pp. IOI-4. W. W. Norton. Originally published in the journal Film Art in 1935 .

Sheets, Hilarie M. (20I6) An artist explores the lives of girls labeled difficult. New York Times (I6 May 20I6, Art and Design section). www.nytimes.com/2016/05/22/arts/ design/an-artist-explores-the-lives-of-girls-labeled-difficult.html. 
Sherman, Rina, ed. (2018) Dans le sillage de Jean Rouch: Témoinages et essais. Éditions de la Maison des sciences de l'homme.

Sillitoe, Paul (2003) Time to be professional? Anthropology Today I9(I): I-2.

Singer, André (1992) Anthropology in broadcasting. In Peter Crawford and David Turton, eds, Film as Ethnography, pp. 264-73. Manchester: Manchester University Press.

- (2006) Tribes and tribulations: a response to Hughes-Freeland. Anthropology Today $22(3): 24-5$.

Singer, André with Steven Seidenberg (1992) Televising culture: the representations of anthropology in British broadcasting. Visual Anthropology Review 8(I): I22-5.

Sjöberg, Johannes (2008a) Ethnofiction: genre hybridity in theory and practice-based research. PhD manuscript. School of Arts Histories and Cultures, University of Manchester.

- (2008b) Ethnofiction: drama as a creative research practice in ethnographic film. Journal of Media Practice 9(3): 229-42.

- (2018) Une sorte de pyschodrame: l'art dramatique comme méthode ethnographique dans les films de Jean Rouch. In Rina Sherman, ed., Dans le sillage de Jean Rouch: Témoinages et essais, pp. 195-208. Paris: Éditions de la Maison des sciences de l'homme.

Staal, J. F. 'Frits' (1989) Anthropologists against death. Society for Visual Anthropology Newsletter 5(I): I4, I9.

Starr, Cecile (I996) Song of Ceylon. An interview with Basil Wright. In Kevin MacDonald and Mark Cousins, eds, Imagining Reality: The Faber Book of Documentary, pp. I02-II. London: Faber \& Faber. Originally published in Film-Maker's Newsletter 9(I) in November 1975 .

Stoller, Paul (1992) The Cinematic Griot: The Ethnography of Jean Rouch. Chicago and London: University of Chicago Press.

Strathern, Andrew (1977) Making 'Ongka's Big Moka'. Cambridge Anthropology. Special Issue Ethnographic Film, pp. 32-46.

Strathern, Marilyn (1997) Comment on 'Televisualist Anthropology' by James F. Weiner. Current Anthropology 38(2): 224-6.

Strecker, Ivo (I988) Filming among the Hamar. Visual Anthropology I (3): 369-78.

Suhr, Christian (2019) Descending with Angels. Islamic Exorcism and Psychiatry: A Film Monograph. Manchester: Manchester University Press.

Sutherland, Anne, ed. (1978) Face Values: Some Anthropological Themes. British Broadcasting Corporation.

Sutton, Mark Q. (2017) An Introduction to Native North America, 5th edn. Abingdon: Routledge.

Taylor, Lucien (1996) Iconophobia: how anthropology lost it at the movies. Transition 69: 64-88.

- (1998a) Introduction. In David MacDougall, Transcultural Cinema, pp. 3-2I. Princeton: Princeton University Press.

- (I998b) 'Visual Anthropology Is Dead, Long Live Visual Anthropology!' American Anthropologist IOO(2): 534-7.

- (2003) A life on the edge of film and anthropology. In Steven Feld, ed., CinéEthnography, pp. I29-46. Minneapolis and London: University of Minnesota Press. Originally published in 199I in Visual Anthropology Review 7(I): 92-IO2.

Tedlock, Barbara (1983) Zuni Sacred Theater. American Indian Quarterly 7(3): 93-IIO.

Thompson, Christopher (1995) De Buñuel à Rouch: les surréalistes devant le documentaire et le film ethnographique. In Christopher W. Thompson, ed., L'Autre et le Sacré: surréalisme, cinéma, ethnologie, pp. 263-8I. Paris: L'Harmattan.

Tierney, Patrick (2000) Darkness in El Dorado: How Scientists and Journalists Devastated the Amazon. New York and London: W. W. Norton.

Tomaselli, Keyan G. and John P. Homiak (I999) Powering popular conceptions: the !Kung in the Marshall family expedition films of the I950s. Visual Anthropology I $2(2-3):$ I53-84. 
Torresan, Angela (20II) Round Trip: Filming a Return Home. Visual Anthropology Review 27(2): II9-30.

Turin, Mark (2003) An Interview with Asen Balikci. Available at www.sms.cam.ac.uk/ media/IIIIS27.

Turner, Terence (1990) Visual media, cultural politics, and anthropological practice: some implications of recent uses of film and video among the Kayapo of Brazil. Commission on Visual Anthropology Review, Spring I990: 8-I3.

- (I99Ia) Representing, resisting, rethinking: historical transformations of Kayapo and anthropological consciousness. In George W. Stocking, ed., Colonial Situations: Essays on the Contextualization of Ethnographic Knowledge. History of Anthropology, vol. 7, pp. 285-313. Madison: University of Wisconsin Press.

- (I99Ib) The social dynamics of video media in an indigenous society: the cultural meaning and the personal politics of video-making in Kayapo communities. Visual Anthropology Review 7(2): 68-76.

- (I992a) Defiant images: the Kayapo appropriation of video. Anthropology Today $8(6): 5-16$.

- (I992b) The Kayapo on television: an anthropological viewing. Visual Anthropology Review 8(I): I07-I2.

- (I995) Representation, collaboration and mediation in contemporary ethnographic and indigenous media. Visual Anthropology Review II (2): I02-6.

- (1997) Comment on 'Televisualist Anthropology' by James F.Weiner. Current Anthropology 38(2): 226-9.

- (2002) Representation, politics, and cultural imagination in indigenous video: general points and Kayapo examples. In Faye D. Ginsburg, Lila Abu Lughod and Brian Larkin, eds, Media Worlds: Anthropology on New Terrain, pp. 75-89. Berkeley and Los Angeles: University of California Press

Turton, David (I988) Looking for a cool place: the Mursi, I890s to I980s. In Douglas Johnson and David Anderson, eds, The Ecology of Survival: Case Studies from Northeast African History, pp. 26I-82. Boulder and London: Westview Press and Lester Crook Academic Publishing.

- (I992a) Anthropology on television: what next? In Peter Crawford and David Turton, eds, Film as Ethnography, pp. 283-99. Manchester: Manchester University Press.

- (1992b) How to make a speech in Mursi. In Peter Crawford and Jan Ketil Simonsen, eds, Ethnographic Film Aesthetics and Narrative Traditions, pp. 159-75. Aarhus: Intervention Press.

Van Vuuren, Lauren (2013) 'The Africa I Know': film and the making of 'Bushmen' in Laurens van der Posts's Lost World of Kalahari (1956). In Joshua A. Bell, Alison K. Brown, and Robert J. Gordon, eds, Recreating First Contact: Expeditions, Anthropology, and Popular Culture, pp. 215-30. Washington DC: Smithsonian Institution Scholarly Press.

Vaughan, Dai (I999) For Documentary: Twelve Essays. Berkeley, Los Angeles, London: University of California Press.

Wanono, Nadine (1987) Ciné-rituel de femmes dogon. Paris: Éditions du CNRS.

- (2006) From spatial analysis to virtual wonder. In Metje Postma and Peter Ian Crawford, eds, Reflecting Visual Ethnography: Using the Camera in Anthropological Research, pp. 252-69. Højbjerg and Leiden: Intervention Press and CNWS Publications.

Weinberger, Eliot (1994) The camera people. In Lucien Taylor, ed., Visualizing Theory: Selected Essay from V.A.R. 1990-1994, pp. 3-26. New York and London: Routledge.

Weiner, James (I997) Televisualist anthropology: representation, aesthetics, politics. Current Anthropology 38(2): 197-235.

Wenger, Tisa (2009) We Have A Religion:The 1920 s Pueblo Dance Controversy and American Religious Freedom. University of North Carolina Press.

Werbner, Richard (1984) The Manchester School in South-Central Africa. Annual Review of Anthropology I3: I57-85.

Werner, François (20I5) The Archives of the Planet: the life and works of Albert Kahn. Visual Anthropology 28(5): 438-50. 
Wiessner, Polly (2003) Owners of the future? Calories, cash, casualties and self-sufficiency in the Nyae Nyae area between 1996 and 2003. Visual Anthropology Review I9(I-2): I49-59.

Wilmsen, Edwin N. (1999) Knowledge as the source of progress: the Marshall family testament to the 'Bushmen'. Visual Anthropology I2(2-3): 213-65.

- (2003) A Kalahari family named Marshall: "I want a record, not a movie". Visual Anthropology Review I9(I-2): II4-27.

Wilson, Pamela and Michelle Stewart, eds (2008) Global Indigenous Media: Cultures, Poetics, and Politics. Durham and London: Duke University Press.

Winston, Brian (1995) Claiming the Real:The Documentary Film Revisited. London: British Film Institute.

- (2000) Lies, Damn Lies and Documentaries. London: British Film Institute.

- (2013) Life as narrativised. In Brian Winston, ed., The Documentary Film Book, pp. 89-97. Palgrave/Macmillan on behalf of the British Film Institute.

Woodhead, Leslie (2006) Making 'The Mursi'. www.mursi.org/documents-and-texts/ published-articles/woodhead-leslie.

Worth, Sol and John Adair (1972) Through Navajo Eyes: An Exploration in Film Communication and Anthropology. Bloomington: Indiana University Press.

Wortham, Erica Cusi (2013) Indigenous Media in Mexico: Culture, Community, and the State. Durham and London: Duke University Press.

Wright, Terence (1992) Television narrative and ethnographic film. In Peter Crawford and David Turton, eds, Film as Ethnography, pp. 274-82. Manchester: Manchester University Press.

Yellen, John (1984) The integration of hunting into prehistoric hunting and gathering economies. In M. Hall and G. Avery, eds, Frontiers: Southern African Archaeology Today, pp. 53-64. Cambridge: Cambridge University Press.

Young, Colin (1982a) MacDougall conversations. RAIN 50: 5-8.

- (1982b) Vérité - the true story. Edinburgh International Television Festival Programme no. 7 , pp. 58-65.

- (I995) Observational cinema. In Paul Hockings, ed., Principles of Visual Anthropology, 2nd edn, pp. 99-II3. Berlin and New York: Mouton de Gruyter.

Young, Colin with Edmund Carpenter (1966) Films made by Americans in the Pacific which have any anthropological or ethnographic significance. See unesdoc.unesco.org/ images/oor4/OoI437/I43776eb.pdf.

ZamoranoVillareal, Gabriela (2017) Indigenous Media and Political Imaginaries in Contemporary Bolivia. Lincoln: University of Nebraska Press.

Zhang, Zhongyun, ed. (n.d.) The Eye of the Villager:Yunnan and Vietnam Community-based Visual Education and Communication. Yunnan Academy of Social Sciences. 